\title{
Intervertebral disc damage models in organ culture: a comparison of annulus fibrosus cross-incision versus punch model under complex loading
}

Daniela A. Frauchiger, MSc $\mathrm{PhD}^{1}$

Samantha C. W. Chan, MSc PhD ${ }^{1}$

Lorin M. Benneker, Prof. MD ${ }^{2}$

Benjamin Gantenbein, Prof. Dr. $\mathrm{PhD}^{1 \times}$

Phone: + 410316315937

Email: Benjamin.Gantenbein@istb.unibe.ch

Tissue and Organ Mechanobiology, Institute for Surgical Technology and Biomechanics, University of Bern, Stauffacherstrasse 78, 3014 Bern, Switzerland

2 Department of Orthopedic Surgery and Traumatology, Insel University Hospital, University of Bern, Freiburgstrasse 4, 3010 Bern, Switzerland

Received: 15 September 2017 / Accepted: 14 May 2018

\section{Abstract \\ Purpose}

Comparison of two annulus fibrosus injury models that mimic intervertebral disc (IVD) herniation, enabling the study of IVD behaviour under three loading regimes in a bovine organ culture model.

AQ1

\section{Methods}


An injury was induced by custom-designed cross-incision tool or a 2-mm biopsy punch in IVDs. Discs were cultured for 14 days under (1) complex (compression and torsion), (2) static, and (3) no load. Disc height, mitochondrial activity, DNA and glycosaminoglycan (GAG) contents, and disc stiffness under complex load were determined. Further, gene expression and histology analysis were performed.

\section{Results}

While both injury models did not change the compressional stiffness of IVDs, cross-incision decreased disc height under complex load. Moreover, under complex load, the biopsy punch injury induced down-regulation of several anabolic, catabol ic, and inflammatory genes, whereas cross-incision did not significantly differ from control discs. However, DNA and GAG contents were in the range of the healthy control discs for both injury models but did show lower contents under no load and static load. Injury side and contralateral side of the IVD showed a similar behaviour on the biochemical assays tested.

AQ2

\section{Conclusion}

Compressional stiffness, GAG and DNA contents, did not differ between injury models under complex load. This behaviour was partially attributed to the positive influence of complex loading on matrix regeneration and cell viability. However, disc height was reduced for the cross-incision. Relative gene expression changes of the inflammatory and anabolic genes for the biopsy punch approach might indicate that induced damage was too intense to trigger any inflammatory or repair response.

\section{Graphical abstract}

These slides can be retrieved under Electronic Supplementary Material. 

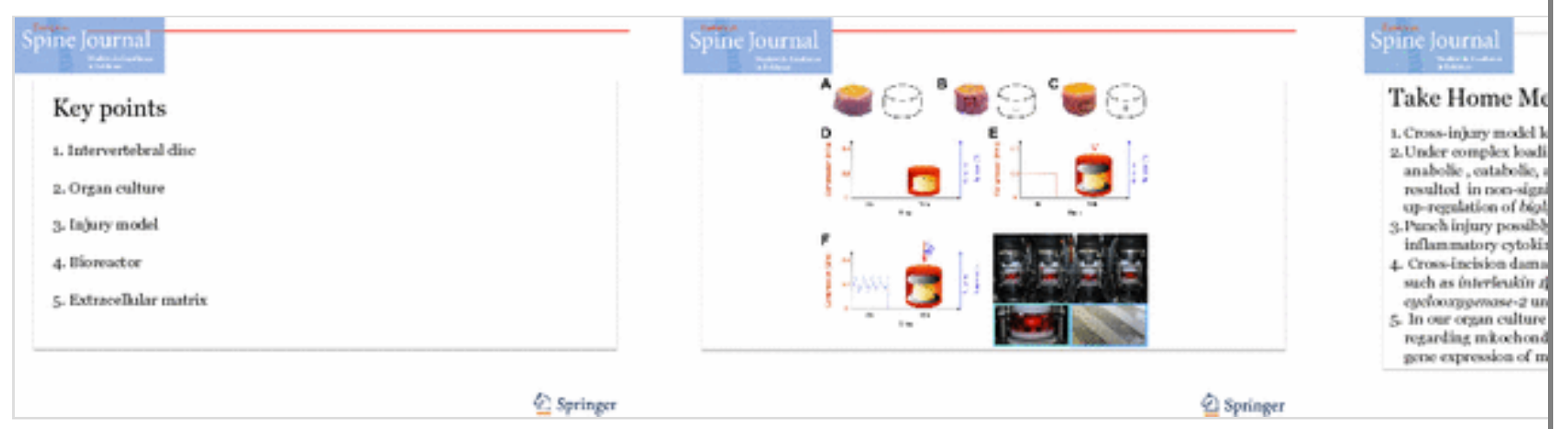

\section{Keywords}

Intervertebral disc

Organ culture

Injury model

Bioreactor

Extracellular matrix

Electronic supplementary material

The online version of this article (https://doi.org/10.1007/s00586-018-5638-5) contains supplementary material, which is available to authorized users.

\section{Introduction}

In our ageing and active society, degeneration and injuries of the intervertebral disc (IVD) are becoming an increasing problem. Around $80 \%$ of the population is at least once in their life affected by low back pain (LBP), which is causing a high socio-economic burden. Organ culture models have been developed in the last decades to study effects of physiological loading and chemical degradation [1]. Several models have been developed to study injury of the IVD (Table 1). Previous studies did not take sufficiently into account the interplay of injury using live cells and different mechanical loading profiles, including combined compression and torsion $[2,3,4,5]$. However, doing so could provide insight into the in vivo mechanobiological behaviour of the disc. Conclusions that can be drawn from such ex vivo mechanical controlled bioreactor experiments could provide valuable input for clinical application and guide prevention and repair [1]. 
Table 1

Overview of IVD injury models

\begin{tabular}{|c|c|c|c|}
\hline Injury & Species & Outcome & References \\
\hline $\begin{array}{l}\text { Needle puncture with } \\
18,22 \text { and } 26 \mathrm{G} \\
\text { needles }\end{array}$ & Rat & $\begin{array}{l}18 \mathrm{G} \text { needle lead to changes in } \\
\text { disc mechanics and cellular } \\
\text { change }\end{array}$ & {$[21]$} \\
\hline $\begin{array}{l}\text { Needle puncture with } \\
18,21,23,25,27 \text { and } \\
29 G \text { needles }\end{array}$ & Rat & $\begin{array}{l}\text { Needles }>21 \mathrm{G} \text { induced large and } \\
\text { rapid degeneration, }<25 \mathrm{G} \text { causes } \\
\text { less severe degenerative changes }\end{array}$ & {$[22]$} \\
\hline $\begin{array}{l}\text { Needle puncture with } \\
25 \text { and } 14 \mathrm{G} \text { needle }\end{array}$ & Bovine & $\begin{array}{l}\text { Rapid degeneration in dynamic } \\
\text { modulus and increase in creep } \\
\text { was induced, but no changes in } \\
\text { height, proteoglycan or water } \\
\text { content was observed. Localised } \\
\text { cell death was seen }\end{array}$ & {$[2]$} \\
\hline $\begin{array}{l}\text { Needle puncture } 29 \\
\text { and } 26 \mathrm{G}\end{array}$ & Mice & $\begin{array}{l}\text { The } 29 \mathrm{G} \text { needle had no adverse } \\
\text { effects, whereas the } 26 \mathrm{G} \text { caused } \\
\text { decrease in compressive, } \\
\text { torsional, and early damping } \\
\text { stiffness. Furthermore, disc } \\
\text { height and GAG content in NP } \\
\text { decreased }\end{array}$ & {$[23]$} \\
\hline $\begin{array}{l}\text { Needle puncture with } \\
30,25 \text { and } 21 \mathrm{G} \\
\text { needle }\end{array}$ & Rat & $\begin{array}{l}\text { All needle sizes caused reduced } \\
\text { elastic stiffness under } \\
\text { compression, whereas torsional } \\
\text { parameters were affected } \\
\text { proportionally by needle size }\end{array}$ & {$[24]$} \\
\hline $\begin{array}{l}\text { Needle puncture with } \\
21 \text { or } 26 \mathrm{G} \text { needle }\end{array}$ & Bovine & $\begin{array}{l}\text { Needle punctures caused } \\
\text { changes in shear strains in the } \\
\text { AF when loaded. Repeated } \\
\text { loading did not cause further } \\
\text { damages upon reaching second } \\
\text { loading cycle }\end{array}$ & {$[4]$} \\
\hline $\begin{array}{l}\text { Scalpel incision } \\
10 \mathrm{~mm} \text { deep at three } \\
\text { locations followed by } \\
\text { endplate fracture }\end{array}$ & Human & $\begin{array}{l}\text { Measured intradiscal pressure } \\
\text { was smaller for scalpel incision } \\
\text { when compared to endplate } \\
\text { fractures }\end{array}$ & {$[25]$} \\
\hline Scalpel blade incision & Pig & $\begin{array}{l}\text { Stab incision led to an altered } \\
\text { collagen composition }\end{array}$ & {$[26]$} \\
\hline Scalpel blade incision & Rat & $\begin{array}{l}\text { Scalpel incision led to reduction } \\
\text { in NP size, disorganisation of AF } \\
\text { structure, and a shift of AF cells } \\
\text { towards chondrocyte-like } \\
\text { phenotype }\end{array}$ & {$[27]$} \\
\hline
\end{tabular}




\begin{tabular}{|c|c|c|c|}
\hline $\begin{array}{l}\text { Cross-incision with a } \\
\text { scalpel blade \#15 }\end{array}$ & Bovine & $\begin{array}{l}\text { Cross-incision followed by } \\
\text { discectomy led to significant cell } \\
\text { viability loss and a trend to disc } \\
\text { height loss }\end{array}$ & {$[28]$} \\
\hline $\begin{array}{l}\text { Needle puncture by } \\
16 \mathrm{G} \text { needle } 5 \mathrm{~mm} \\
\text { deep }\end{array}$ & Rabbit & $\begin{array}{l}\text { MRI images as well as histology } \\
\text { indicate slowly progressing disc } \\
\text { degeneration }\end{array}$ & [29] \\
\hline $\begin{array}{l}\text { Biopsy punch ( } \varnothing \\
4 \mathrm{~mm}) \text { through } \\
\text { endplate vs through } \\
\text { AF }\end{array}$ & Bovine & $\begin{array}{l}\text { After closure of the defect by } \\
\text { suture (AF injury) or PMMA (EP } \\
\text { approach), no significant } \\
\text { difference could be found among } \\
\text { them }\end{array}$ & {$[7]$} \\
\hline Mechanical loading & Human & $\begin{array}{l}\text { When testing different loading } \\
\text { conditions, the highest load led } \\
\text { to a significant decrease in cell } \\
\text { viability }\end{array}$ & [15] \\
\hline Wedge loading & Bovine & $\begin{array}{l}\text { The asymmetric loading caused a } \\
\text { degenerative effect on the tissue } \\
\text { and cells }\end{array}$ & [19] \\
\hline $\begin{array}{l}\text { Mini-trephine } \\
\text { (1.8 mm wide, } 4 \mathrm{~mm} \\
\text { deep) and } 16 \mathrm{G} \text { needle } \\
\text { injury ( } 5 \mathrm{~mm} \text { deep) }\end{array}$ & Rabbit & $\begin{array}{l}\text { Both injury models led to disc } \\
\text { degeneration and loss of GAG }\end{array}$ & {$[30]$} \\
\hline $\begin{array}{l}\text { Box-cut by scalpel } \\
(4.5 \times 4.5 \mathrm{~mm})\end{array}$ & Bovine & $\begin{array}{l}\text { Injured IVDs showed significant } \\
\text { height loss and a decrease in } \\
\text { GAG content }\end{array}$ & [31] \\
\hline $\begin{array}{l}\text { End plate burst } \\
\text { fractures and end } \\
\text { plate puncture with } \\
18 \mathrm{G} \text { needle }\end{array}$ & Rabbit & $\begin{array}{l}\text { Burst fraction caused big loss of } \\
\text { GAG/DNA after } 28 \text { days. End } \\
\text { plate puncture led to changes } \\
\text { from control discs but was less } \\
\text { severe than the burst fracture }\end{array}$ & {$[32,33]$} \\
\hline $\begin{array}{l}\text { End plate fracture } \\
\text { with physiologic } \\
\text { post-traumatic } \\
\text { dynamic loading and } \\
\text { or peripheral blood } \\
\text { mononuclear cell } \\
\text { treatment }\end{array}$ & Rabbit & $\begin{array}{l}\text { The injured IVDs with loading } \\
\text { and cell supplement showed } \\
\text { signs of disc degeneration. This } \\
\text { was independent of the post- } \\
\text { traumatic loading. Cells were not } \\
\text { able to home the discs but did } \\
\text { aggravate degenerative changes }\end{array}$ & [34] \\
\hline
\end{tabular}

In the present study, two annular disc injury models - i.e. a biopsy punch and a cross-incision model - were compared to mimic partial discectomy after herniation versus AF injury crossed with three different loading regimes. Both of these injury models supposedly mimic disc herniation; the biopsy punches 
the situation after surgery and the cross-incision a possible pre-herniation situation, somewhat similar to needle puncture [2]. Moreover, it has been shown that after disc herniation surgery, partial or complete discectomy, degeneration may occur [6]. This injury model also has been recently successfully applied to assess biomaterials ex vivo [7]. The second injury model was induced by the newly designed cross-incision tool that we introduce in this study. On the one hand, we expected that the novel tool increased reproducibility as incision depth could be more controlled. On the other hand, a higher number of AF fibres were affected by the cut, and this might not necessarily cause double the damage as demonstrated by Adams et al. [8]. Additionally, we investigated the effect of three different loading profiles onto the two injury models, an aspect that is neglected in most previous publications investigating mechanobiology of the IVD [9].

We hypothesised here that the wound model induced by the cross-incision tool results in more significant damage, regarding reduced disc height, matrix production, DNA content, and down-regulation of anabolic genes, as compared to the biopsy punch, despite more substantial tissue loss. We hypothesised furthermore that these differences in damage occurred mainly by the application of complex mechanical loading, including compression and torsion; especially the AF injury by cross-incision would respond more specifically to a "twisted" motion, which we defined as compression and torsion movement $[10,11]$.

\section{Materials and Methods}

\section{Bovine IVD isolation and organ culture}

Bovine tails of 10- to 14-month-old animals were obtained from a local abattoir only hours after slaughter. 4-8 coccygeal IVDs of similar sizes were isolated from the mid of the tail ( $\mathrm{Cd} 4-6$ to $\mathrm{Cd} \mathrm{10-12)} \mathrm{and} \mathrm{under} \mathrm{aseptic} \mathrm{conditions} \mathrm{as}$ described here [12]. After the excision of IVDs along the cartilaginous endplate (EP), disc weight and disc height were measured from EP to EP, and diameters were directly measured twice. Both disc diameter and height were measured at two locations, shifted by $90^{\circ}$. For disc height, it was ensured that the disc was placed completely between the outer jaws of the calliper and that the EPs were aligned horizontally. The measurements were repeated before the experiment and at the end of the culture. After isolation, IVDs were left for equilibration 
for approximately $17 \mathrm{~h}$ in high-glucose Dulbecco's modified Eagles medium (HG-DMEM) (Gibco, Thermo Fisher Scientific, USA), supplemented with 5\% foetal calf serum (FCS) and 1\% penicillin/streptomycin. The next day injury was induced, by either biopsy punch or cross-incision, and IVDs were cultured in HG-DMEM for 14 days under three different loading conditions: (1) free swelling where the discs were kept in the medium, (2) static load of $0.2 \mathrm{MPa}$ for $8 \mathrm{~h} /$ day, and (3) complex loading $0.2 \mathrm{MPa}$ and torsion of $0^{\circ} \pm 2^{\circ}$ at a frequency of $0.2 \mathrm{~Hz}$ for $8 \mathrm{~h} /$ day. The complex loading regime was adapted from Chan et al. [9] and was performed in a custom-designed, force-controlled, two-degreeof-freedom (2DoF) bioreactor allowing for compression and torsion [10] (Fig. 1). In addition to the injured discs, healthy control IVDs were subjected to the same three loading conditions (each, $N=5$ ) in order to normalise downstream assays. An overview of all sample groups can be found in Table 2. Discs of different levels were randomised to minimise level effects, and media was refreshed every 2-3 days.

\section{Fig. 1}

Overview of organ culture. Pictures of bovine IVD experimental groups as cut-out units and as cross section a untreated "healthy" control, b $22 \mathrm{~mm}$-punch - ... mm punch, and c cross-incision injury. Loading profiles for d no load (= free swelling), e static load of $0.2 \mathrm{MPa}$ for $8 \mathrm{~h} /$ day and f Left: Complex load with compression of $0.2 \mathrm{MPa}$ and $\pm 2^{\circ}$ of torsion at $0.2 \mathrm{~Hz}$ for $8 \mathrm{~h} /$ day. Right: Bioreactor used for the complex loading. Close-up shows a single station and titanium grid to prevent discs from sliding during torsion and allow media diffusion 


\section{A}
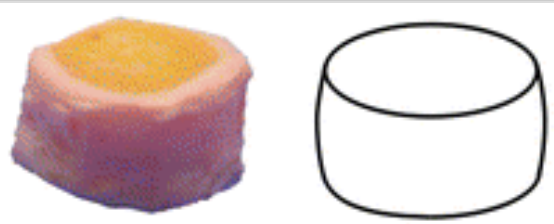

D

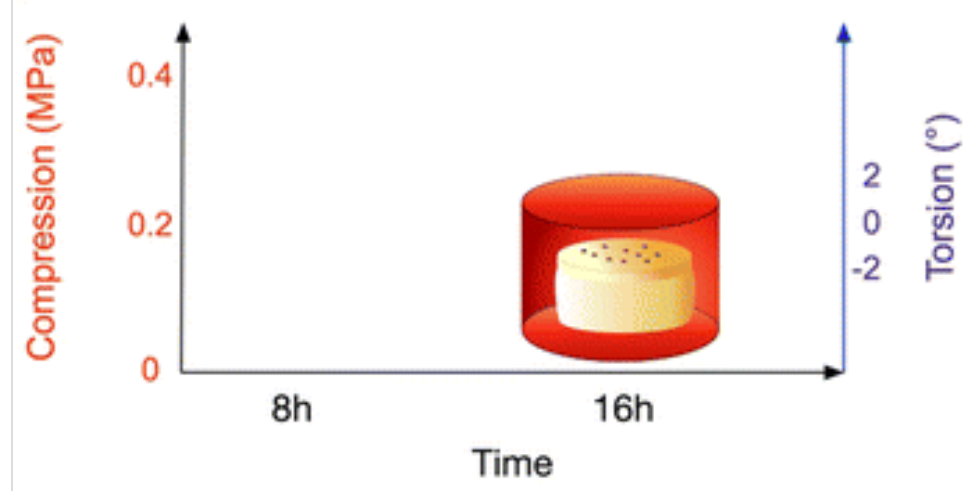

$\mathbf{F}$

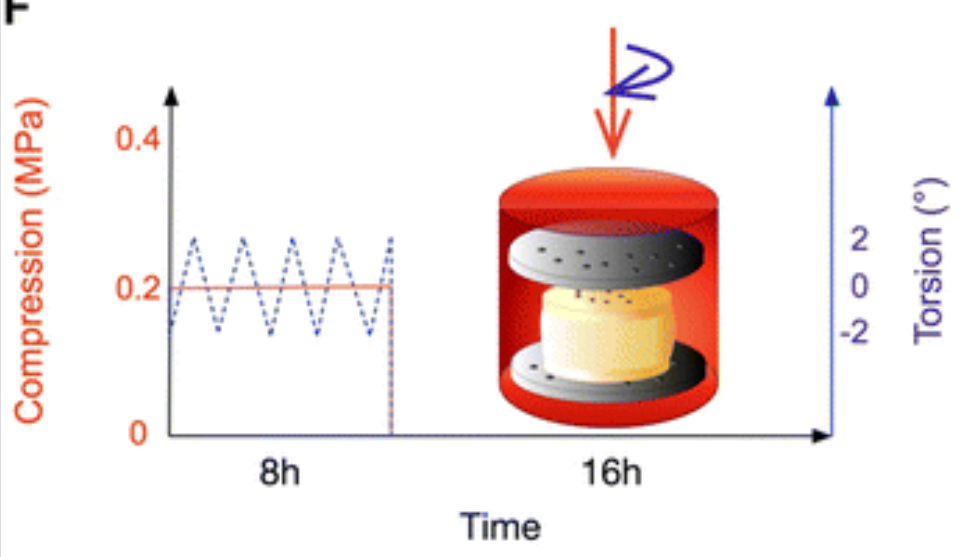

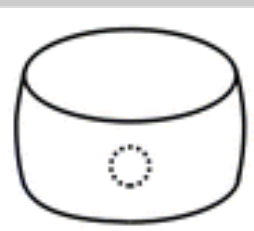

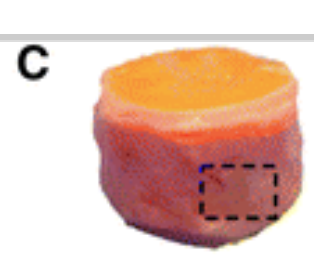

E
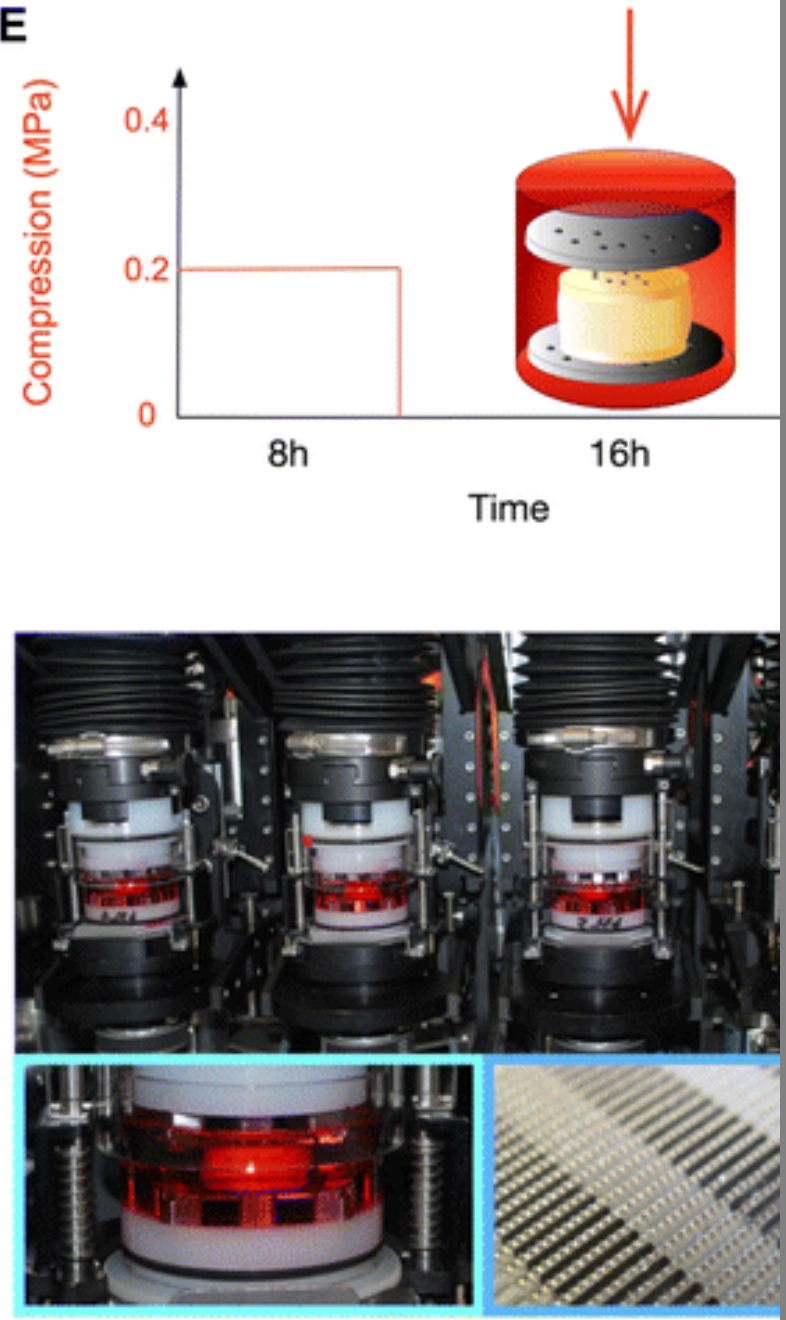

Table 2

Overview of sample groups and sample number

\begin{tabular}{l|l|l|}
$\begin{array}{l}\text { Sample group } \\
\text { No load }\end{array}$ & Sample number $(\boldsymbol{N})$ \\
\hline Healthy control & 6/(IVD height, mitochondrial activity, DNA, GAG =5) \\
\hline Biopsy punch injury & 6/(IVD height, mitochondrial activity, DNA, GAG =5) \\
\hline Cross-incision injury & 6/(IVD height, mitochondrial activity, DNA, GAG =5) \\
\hline Histology (cryo) & 1 \\
\hline
\end{tabular}




\begin{tabular}{l|l}
$\begin{array}{l}\text { Histology (PMMA) } \\
\text { Static load }\end{array}$ & 1 \\
\hline $\begin{array}{l}\text { Healthy control } \\
\text { Biopsy punch injury }\end{array}$ & $6 /($ IVD height, mitochondrial activity, DNA, GAG $=5)$ \\
\hline $\begin{array}{l}\text { Cross-incision injury } \\
\text { Histology (cryo) }\end{array}$ & $6 /($ IVD height, mitochondrial activity, DNA, GAG $=5)$ \\
\hline Histology (PMMA) & 1 \\
\hline $\begin{array}{l}\text { Complex load } \\
\text { Healthy control }\end{array}$ & $6 /($ IVD height, mitochondrial activity, DNA, GAG $=5)$ \\
\hline $\begin{array}{l}\text { Biopsy punch injury } \\
\text { Cross-incision injury }\end{array}$ & $6 /($ IVD height, mitochondrial activity, DNA, GAG $=5)$ \\
\hline Histology (cryo) & 1 \\
\hline Histology (PMMA) & 1 \\
\hline
\end{tabular}

\section{Injury model}

A 7-mm-deep punch injury was induced by a circular 2-mm biopsy punch (Polymed Medical Center, Switzerland) similar as in the study by Li et al. [7]. This punching resulted in a penetration depth of $49.46 \pm 12.75 \%$ (mean $\pm \mathrm{SD}$ ) in mean disc diameter, a penetration width of $18.83 \pm 10.03 \%$ in mean disc diameter and penetration width of $9.53 \pm 1.34 \%$ in disc height. The core of the punch was removed to form a cavity as previously described [7]. Cross-incision injury was performed using a custom-made tool that represented an evolution of previously established scalpel incision models to induce AF injury and disc degeneration (Fig. 2). The tool is made from stainless steel and is fully autoclavable, except the commercial single-use blade. The blade can be placed before every use by tightening two screws. The tool is designed to allow for highly reproducible cuts shifted $90^{\circ}$ of 7--mm depth and 2--mm width forming a cross and resulting in cutting AF fibres. Depth was controlled by the guidance slit that allows only for $90^{\circ}$ turns and 7--mm depth. The two injury models were 
then normalised to untouched healthy control IVDs that were subjected to the respective loading regime.

\section{Fig. 2}

Fully autoclavable custom-designed cross-incision tool. a Picture of the disassembled device. The guidance of the outer cylinder results in highly reproducible $90^{\circ}$ shifted cuts into the IVD. b Drawing of the use of the tool (1) place tool on IVD (2) push the inner cylinder down into the first guidance slit to create a 7-mm-deep cut, (3) retract the inner cylinder and turn $90^{\circ},(4)$ push down into the second guidance slit to create a second $7-\mathrm{mm}$-deep cut shifted exactly $90^{\circ}$

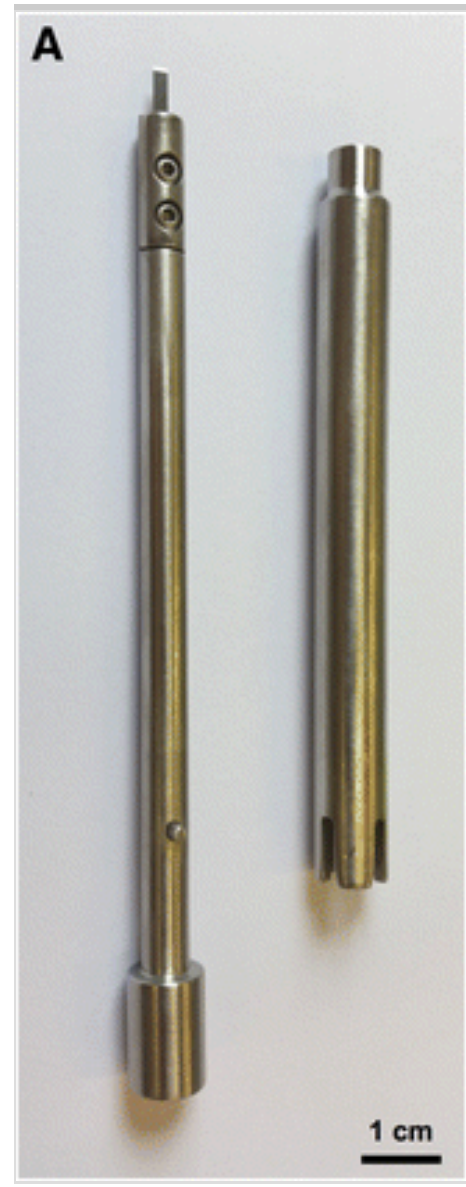

B

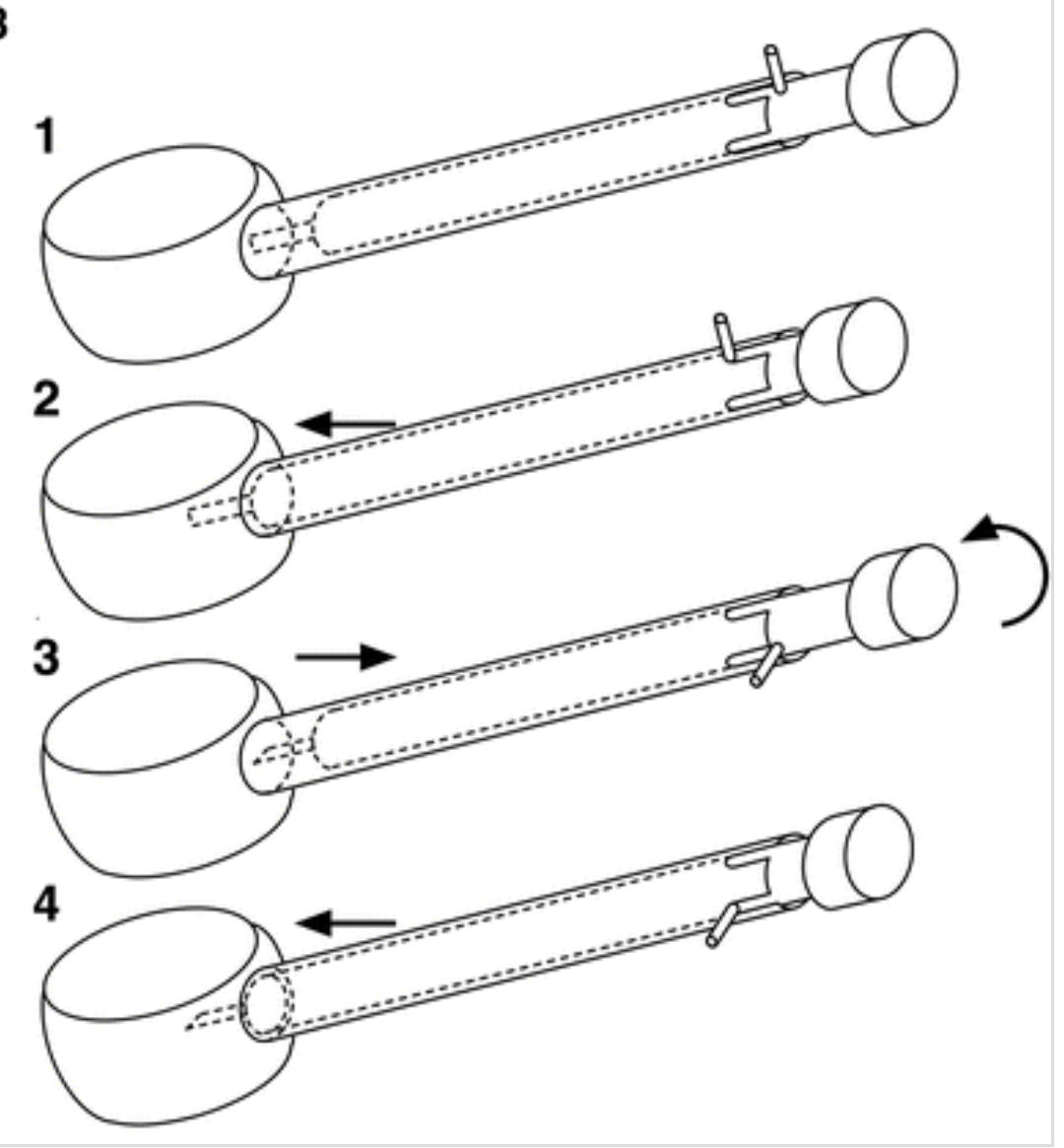

The two injury models were then normalised to untouched healthy control IVDs that were subjected to the respective loading regime.

\section{Cell activity}

Mitochondrial activity was determined to perform alamar blue assay using $50 \mu \mathrm{M}$ resazurin sodium salt (Sigma-Aldrich, Switzerland). Tissue samples 
(wet: $383.95 \pm 184.04 \mathrm{mg}$; dry: $49.35 \pm 22.23 \mathrm{mg}$; mean \pm SD) were taken next to the injury (injured) and from the opposite side (intact) of the disc. Then samples were incubated for $4 \mathrm{~h}$ before reading relative fluorescence units (RFUs) at an excitation wavelength of $547 \mathrm{~nm}$ and an emission wavelength of $582 \mathrm{~nm}$ on an ELISA reader (SpectraMax M5, Molecular Devices

XXX Switzerland ). Data were normalised to the dry weight of tissue samples and normalised to healthy control discs.

AQ5

\section{DNA content}

Alamar blue assay samples were dried overnight at $60{ }^{\circ} \mathrm{C}$ and were digested with $3.9 \mathrm{U} / \mathrm{mL}$ papain from Papaya latex (Sigma-Aldrich). DNA was measured by a bisbenzimide fluorescent dye (Hoechst 3258, Sigma-Aldrich) at $350 \mathrm{~nm}$ excitation and $450 \mathrm{~nm}$ emission wavelength. A standard curve from calf thymus DNA (Sigma-Aldrich) was used to calculate DNA content. Data were normalised to dry weight and healthy control discs.

\section{GAG content}

The same papain digested samples were used for GAG and proteoglycan content determination. For this, 1,9-dimethyl-methylene blue (Sigma-Aldrich) was used, and absorbance was read at $600 \mathrm{~nm}$ with an ELISA reader [13]. GAG content was calculated from a standard curve obtained from chondroitin sulphate (Sigma-Aldrich). Data were normalised to dry weight and healthy control discs.

\section{Gene expression}

Gene expression of several major IVD catabolic (matrix metallopeptidase 3 [MMP3] and 13 [MMP13], ADAM metallopeptidase with thrombospondin type 1 motif 4 [ADAMTS4]), anabolic (aggrecan [ACAN], collagen type I [COL1] and type II [COL2], biglycan $[B G N]$, cartilage oligomeric matrix protein $[C O M P]$ ), and additionally several inflammatory marker genes (interleukin 1 beta $[I L-1 b]$ and $8[I L-8]$, chemokine (C-C motif) ligand 2 [CCL2], cyclooxygenase-2 [COX2], and nerve growth factor $[N G F]$ ) was analysed using quantitative polymerase chain reaction (qPCR). RNA isolation was performed as mentioned here [10]. DNase (DNase $1 \mathrm{Kit}$, Sigma-Aldrich) was used to 
degrade residual DNA, and iScript ${ }^{\mathrm{TM}}$ cDNA Synthesis Kit (Bio-Rad Inc., XXX Switzerland ) was used for reverse transcription. cDNA was mixed with iTaq ${ }^{\mathrm{TM}}$ universal SYBR ${ }^{\circledR}$ Green Supermix (Bio-Rad) and forward and reverse primer (Microsynth, XXX Switzerland ...) for each gene (Table 3). qPCR was performed in duplicates (iQ5, Bio-Rad) using $18 \mathrm{~S}$ as a reference gene, the relative gene expression was determined using the $2^{-\Delta \Delta C t}$ method [14], and data were normalised to healthy control discs.

\section{Table 3}

List of primers used for the two-step qPCR. The annealing temperature was $57^{\circ} \mathrm{C}$ and a two-step protocol with 45 cycles was used.

\begin{tabular}{|c|c|c|c|}
\hline Gene & Description & $\begin{array}{l}\text { Forward primer } \\
\left(5^{\prime}-3^{\prime}\right)\end{array}$ & $\begin{array}{l}\text { Reverse primer } \\
\left(3^{\prime}-5^{\prime}\right)\end{array}$ \\
\hline $18 \mathrm{~S}$ & $18 \mathrm{~S}$ ribosomal RNA & $\begin{array}{l}\text { ACG GAC AGG } \\
\text { ATT GAC AGA } \\
\text { TTG }\end{array}$ & $\begin{array}{l}\text { CCA GAG TCT } \\
\text { CGT TCG TTA } \\
\text { TCG }\end{array}$ \\
\hline ACAN & Aggrecan & $\begin{array}{l}\text { GGC ATC GTG } \\
\text { TTC CAT TAC } \\
\text { AG }\end{array}$ & $\begin{array}{l}\text { ACT CGT CCT } \\
\text { TGT CTC CAT } \\
\text { AG }\end{array}$ \\
\hline COL1 & $\begin{array}{l}\text { Collagen type I alpha } 2 \\
\text { chain }\end{array}$ & $\begin{array}{l}\text { GCC TCG CTC } \\
\text { ACC AAC TTC }\end{array}$ & $\begin{array}{l}\text { AGT AAC CAC } \\
\text { TGC TCC ATT } \\
\text { CTG }\end{array}$ \\
\hline COL2 & $\begin{array}{l}\text { Collagen type II alpha } 1 \\
\text { chain }\end{array}$ & $\begin{array}{l}\text { CGG GTG AAC } \\
\text { GTG GAG AGA } \\
\text { CA }\end{array}$ & $\begin{array}{l}\text { GTC CAG GGT } \\
\text { TGC CAT TGG } \\
\text { AG }\end{array}$ \\
\hline BGN & Biglycan & $\begin{array}{l}\text { CTG CCA CTG } \\
\text { CCA TCT GAG }\end{array}$ & $\begin{array}{l}\text { TTG TTC ACG } \\
\text { AGG ACC AAG } \\
\text { G }\end{array}$ \\
\hline COMP & $\begin{array}{l}\text { Cartilage oligomeric } \\
\text { matrix protein }\end{array}$ & $\begin{array}{l}\text { TGC GAC GAC } \\
\text { GAC ATA CAC }\end{array}$ & $\begin{array}{l}\text { ATC TCC TAC } \\
\text { ACC ATC ACC } \\
\text { ATC }\end{array}$ \\
\hline MMP3 & Matrix metallopeptidase 3 & $\begin{array}{l}\text { CTT CCG ATT } \\
\text { CTG CTG TTG } \\
\text { CTA TG }\end{array}$ & $\begin{array}{l}\text { ATG GTG TCT } \\
\text { TCC TTG TCC } \\
\text { CTT G }\end{array}$ \\
\hline MMP13 & $\begin{array}{l}\text { Matrix metallopeptidase } \\
13\end{array}$ & $\begin{array}{l}\text { TCC TGG CTG } \\
\text { GCT TCC TCT } \\
\text { TC }\end{array}$ & $\begin{array}{l}\text { CCT CGG ACA } \\
\text { AGT CTT CAG } \\
\text { AAT CTC }\end{array}$ \\
\hline ADAMTS4 & $\begin{array}{l}\text { ADAM metallopeptidase } \\
\text { with thrombospondin type } \\
1 \text { motif } 4\end{array}$ & $\begin{array}{l}\text { GGC ACT GGG } \\
\text { CTA CTA TTA C }\end{array}$ & $\begin{array}{l}\text { TGG ACA CAG } \\
\text { ACT GAG GAG }\end{array}$ \\
\hline
\end{tabular}




\begin{tabular}{|c|c|c|c|}
\hline IL-1b & Interleukin 1 beta & $\begin{array}{l}\text { AGT GCC ATC } \\
\text { CTT CTG TCA }\end{array}$ & $\begin{array}{l}\text { CAT TGC CTT } \\
\text { CTC CGC TAT T }\end{array}$ \\
\hline IL-8 & Interleukin 8 & $\begin{array}{l}\text { CTT GTT CAA } \\
\text { TAT GAC TTC } \\
\text { CA }\end{array}$ & $\begin{array}{l}\text { CCA CTC TCA } \\
\text { ATA ACT CTC A }\end{array}$ \\
\hline CCL2 & $\begin{array}{l}\text { Chemokine ( } \mathrm{C}-\mathrm{C} \text { motif) } \\
\text { ligand } 2\end{array}$ & $\begin{array}{l}\text { TCG CCT GCT } \\
\text { GCT ATA CAT T }\end{array}$ & $\begin{array}{l}\text { TTG CTG CTG } \\
\text { GTG ACT CTT }\end{array}$ \\
\hline $\operatorname{cox} 2$ & Cyclooxygenase- 2 & $\begin{array}{l}\text { GGT AAT CCT } \\
\text { ATA TGC TCT } \\
\text { C }\end{array}$ & $\begin{array}{l}\text { GTA TCT TGA } \\
\text { ACA CTG AAT G }\end{array}$ \\
\hline NGF & Nerve growth factor & $\begin{array}{l}\text { ATG TTG TTC } \\
\text { TAC ACT CTG }\end{array}$ & $\begin{array}{l}\text { ATG CTG AAG } \\
\text { TTT AAT CCA }\end{array}$ \\
\hline
\end{tabular}

\section{Stiffness}

During complex loaded organ culture, the applied force and the displacement (equal to IVD disc height) were recorded by the bioreactor. These raw data were subsequently used to calculate the compressive stiffness $[\mathrm{N} / \mathrm{mm}]$ of the discs under complex load. Three hours after the start of the loading cycle when the load stabilized $3 \mathrm{~h}$ were analysed to determine the stiffness by dividing the mean force $[\mathrm{N}]$ by the displacement $[\mathrm{mm}]$.

\section{Histology}

IVDs were fixed in $4 \%$ buffered formaldehyde, followed by immersion in 15 and 30\% sucrose. After EP removal, samples were frozen in O.C.T.TM Compound (Sysmex, XXX Switzerland ) and cut into 16- $\mu \mathrm{m}$ transversal sections. For PMMA embedding, fixed IVDs were dehydrated and infiltrated with xylol prior PMMA embedding. Sagittal PMMA sections were cut at $6 \mu \mathrm{m}$. Haematoxylin \& Eosin (H\&E), Safranin-O/Fast-Green was performed for both cryo and PMMA sections. Additionally, Picrosirius Red staining was performed on PMMA section. Photographs were taken using a Nikon Eclipse 800 (Nikon, Japan), and Autostitch (University of British Columbia, Canada) was used to align photographs.

\section{Statistics}


Statistical analysis among groups for normally distributed data, i.e. DNA, GAG, disc height, and mitochondrial activity, was performed using two-way ANOVA followed by Bonferroni's multiple comparisons tests for injury model and loading profile. The significance is indicated by letters in graphs. Further, one sample $t$ test with a hypothetical value of zero was performed and indicated by asterisks. For these parameters, the graphs show mean values \pm SEM of an $N=$ 5. For gene expression values, we assumed nonparametric distribution and results are presented as mean values \pm SEM of a sample size of $N=6$. Thus, we performed Kruskal-Wallis (K-W) tests and Dunn's multiple pairwise comparison tests. Additionally, Wilcoxon signed rank test was calculated to test deviations from the hypothetical value of 1 . All tests were run on GraphPad Prism version 6.0h (GraphPad Software, California, USA).

\section{Results}

\section{Disc height}

Measurement of disc height at the start and end of the experiment followed by normalisation to a healthy control showed a significant decrease for crossincision injury under complex load ( $p$ value <0.01) (Fig. 3a). Further, no significant disc height change was determined among injury models.

\section{Fig. 3}

a Disc height over culture period relative to "healthy" control IVD, b mitochondrial activity (resazurin salt) of IVD tissue pieces after 14 days of culture under respective conditions and loadings. The papain digested tissue was analysed for c matrix production via glycosaminoglycan (GAG) content and $\mathbf{d}$ DNA content (Hoechst). All data were normalised to the dry weight of tissue samples and to healthy control discs, mean \pm SEM, $N=5$. $p$ values $a^{*}<0.05, b{ }^{* * *}$ $<0.01$

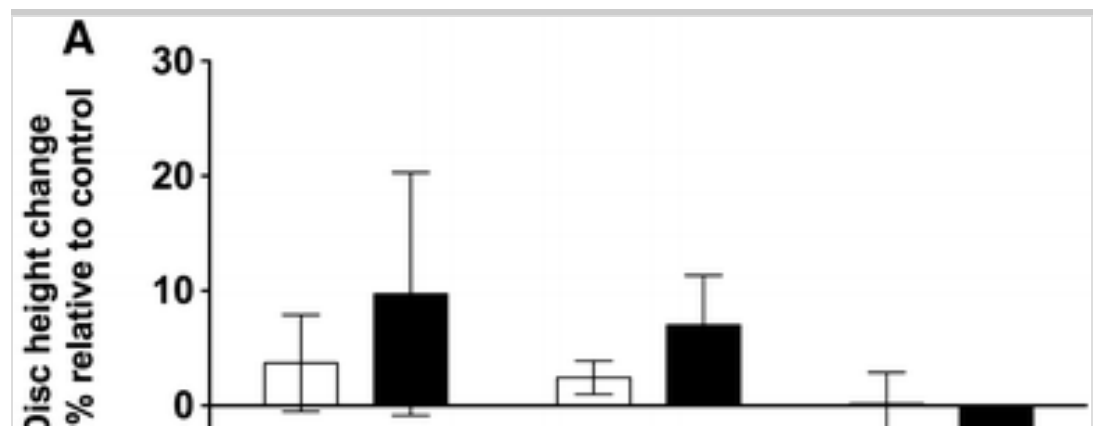



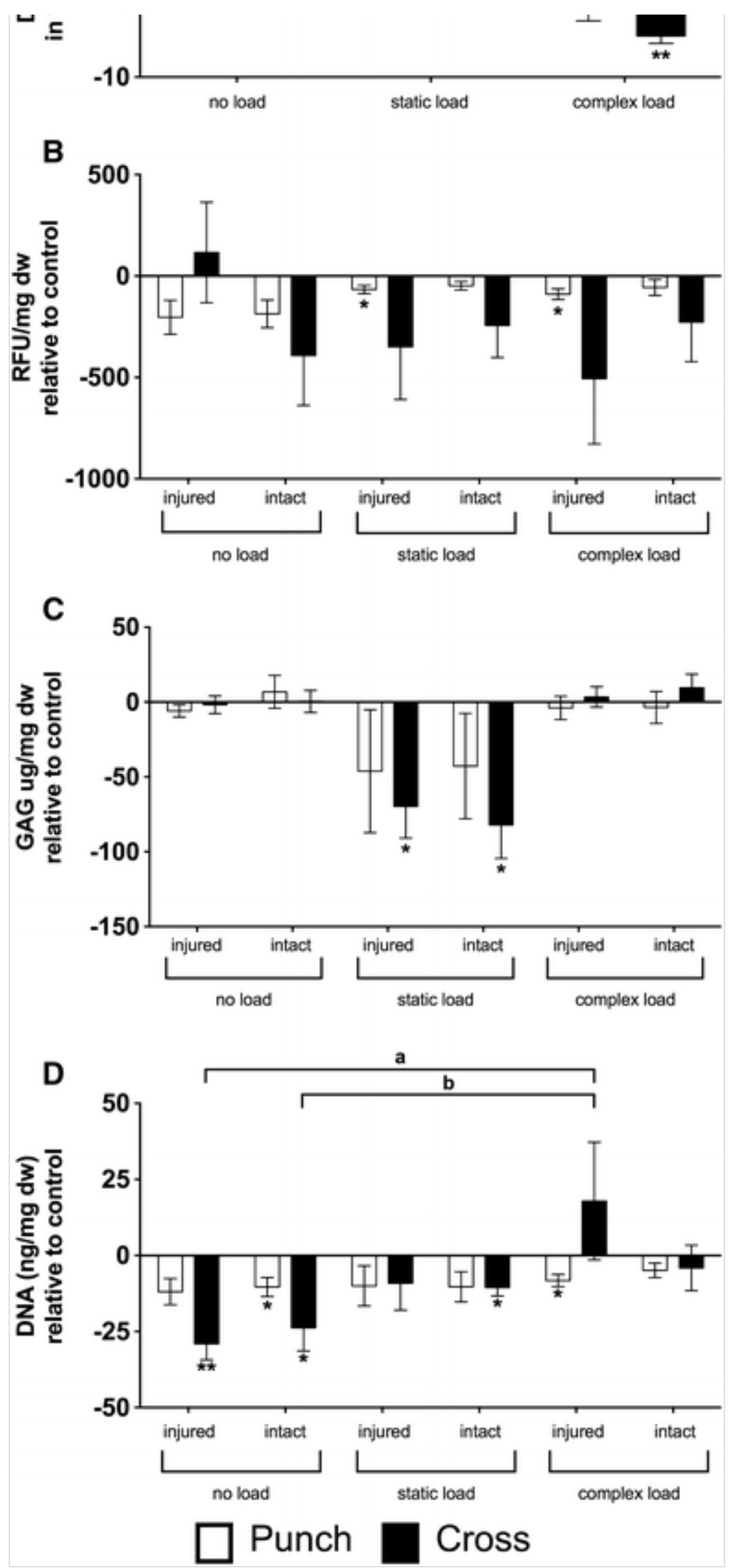


\section{Mitochondrial activity}

In the case of punch injury under static and complex load, lower mitochondrial activity was measured relative to the control ( $p$ value static load, complex load: $<0.05)$. Otherwise, no difference between injury models could be determined (Fig. 3b).

\section{Extracellular matrix and DNA contents}

Matrix content determined from two tissue samples per disc, injury side and contralateral side, showed the lowest GAG concentrations compared to the healthy disc for the statically loaded punch (injured: $-46.17 \pm 41.06 \mu \mathrm{g} / \mathrm{mg}$ $\mathrm{dw}$; intact: $-42.79 \pm 35.22 \mu \mathrm{g} / \mathrm{mg} \mathrm{dw}$ ) and cross-incision (injured: $-69.78 \pm$ $21.13 \mu \mathrm{g} / \mathrm{mg} \mathrm{dw}$, intact: $-82.12 \pm 22.34 \mu \mathrm{g} / \mathrm{mg} \mathrm{dw}$, both sided $p$ value $<0.05$ ) injuries. GAG content under no load or complex load did not show significant changes between injury models or from control samples (Fig. 3c).

DNA content was higher under complex load for the injured side of crossincision $(17.87 \pm 19.34 \mathrm{ng} / \mathrm{mg} \mathrm{dw})$ than under no load for the cross-incision (injured: $-29.07 \pm 5.28 \mathrm{ng} / \mathrm{mg} \mathrm{dw} p$ value $<0.01$, intact $-23.79 \pm 7.63 \mathrm{ng} / \mathrm{mg}$ $\mathrm{dw} p$ value $<0.05$ ). This could not be observed for the punch injury. Additionally, both sides of cross-incision injury IVDs contained less DNA than healthy control discs in the case of no load (injured: $=-29.07 \pm 5.28 \mathrm{ng} / \mathrm{mg} \mathrm{dw} p$ value $<0.01$, intact: $-23.79 \pm 7.63 \mathrm{ng} / \mathrm{mg} \mathrm{dw} p$ value $<0.05)$. Moreover, the intact side under static load possessed less DNA $(=-10.52 \pm 2.83 \mathrm{ng} / \mathrm{mg} \mathrm{dw} p$ value: 0.05$)$. Also, punch injury samples contained less DNA than the control in the case of no load (intact: $=-10.39 \pm 3.14 \mathrm{ng} / \mathrm{mg} \mathrm{dw}, p$ value $<0.05$ ) and complex load (injured: $-8.28 \pm 2.01 \mathrm{ng} / \mathrm{mg} \mathrm{dw}, p$ value $<0.05$ ), Fig. $3 \mathrm{~d}$.

\section{Gene analysis}

Punch injury showed down-regulation of COL1 in comparison with control for complex loaded IVDs for injured side ( $p$ value $<0.05, \sim$ fivefold) (Fig. 4). Further more change BGN to BGN (italics) , BGN was up-regulated under complex load in the cross-incision group on the contralateral side (fourfold, $p$ value $<0.05)$, whereas the injured side of the punch injury was down-regulated ( $p$ value $<0.05$, fourfold). Cross-incision relative to punch-injured disc differed significantly $(\mathrm{K}-\mathrm{W} p$ value $<0.05)$. For $C O M P$, down-regulation was observed 
for both injury models, although under different loading regimes. Cross-incision caused down-regulation under no load and the injured side (twofold, $p$ value $<$ 0.05 ), whereas punch injury caused down-regulation under complex load (injured threefold $p$ value $<0.05$ ).

\section{Fig. 4}

Gene expression of major anabolic genes relative to "healthy" control disc. Kruskal-Wallis tests followed by Dunn's multiple pairwise comparison test were performed among experimental groups. Additionally, Wilcoxon signed rank test was calculated to test deviations from the hypothetical value of $1 . p$ values $*<$ $0.05 ; * *<0.01 ; * * *<0.001, N=6$, mean \pm SEM 


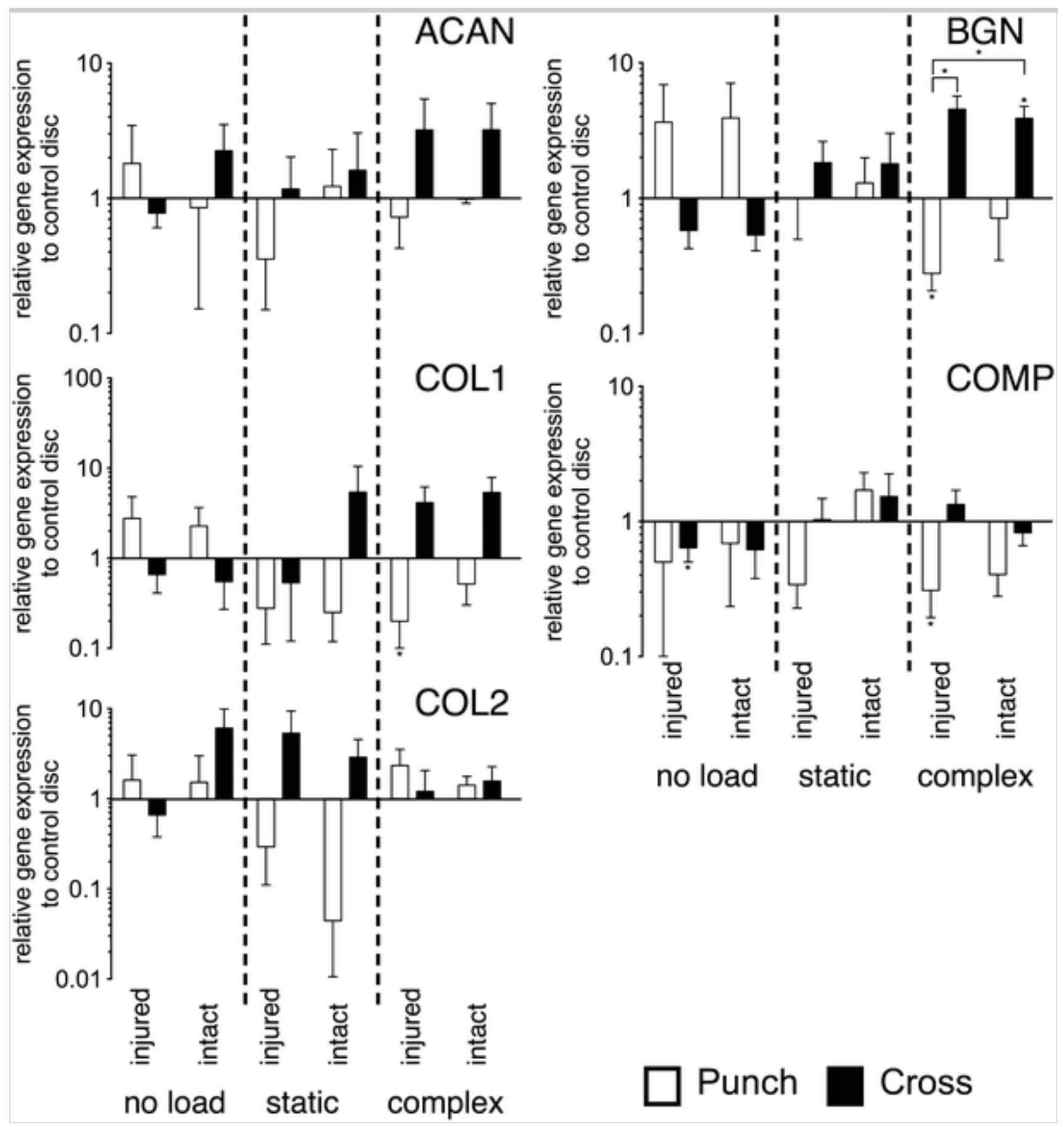

Matrix degeneration was assessed by gene expression of $M M P 3, M M P 13$, and ADAMTS4 and revealed down-regulation mainly for punch injury and predominantly for no load (Fig. 5). MMP3 was down-regulated for punch injury under no load (injured fivefold and intact fourfold, both $p$ value $<0.05$ ) and under complex load (injured fourfold, $p$ value $<0.05$ ). Cross-incision, however, did not show any significant deviations from the control. Also, MMP13 was down-regulated for punch injury under no load (injured 20-fold and intact ninefold, both $p$ value $<0.05$ ) and complex load (injured ttenfold, $p$ value $<$ 
0.05). For cross-incision, down-regulation was found under static load on the injured side (eightfold, $p$ value $<0.05$ ). Finally, ADAMTS4 did not show any significant changes.

\section{Fig. 5}

Gene expression of major catabolic genes relative to "healthy" control disc. Kruskal-Wallis tests followed by Dunn's multiple pairwise comparison test were performed among experimental groups. Additionally, Wilcoxon signed rank test was calculated to test deviations from the hypothetical value of $1 . p$ values $*<$ $0.05 ; * *<0.01 ; * * *<0.001, N=6$, mean \pm SEM

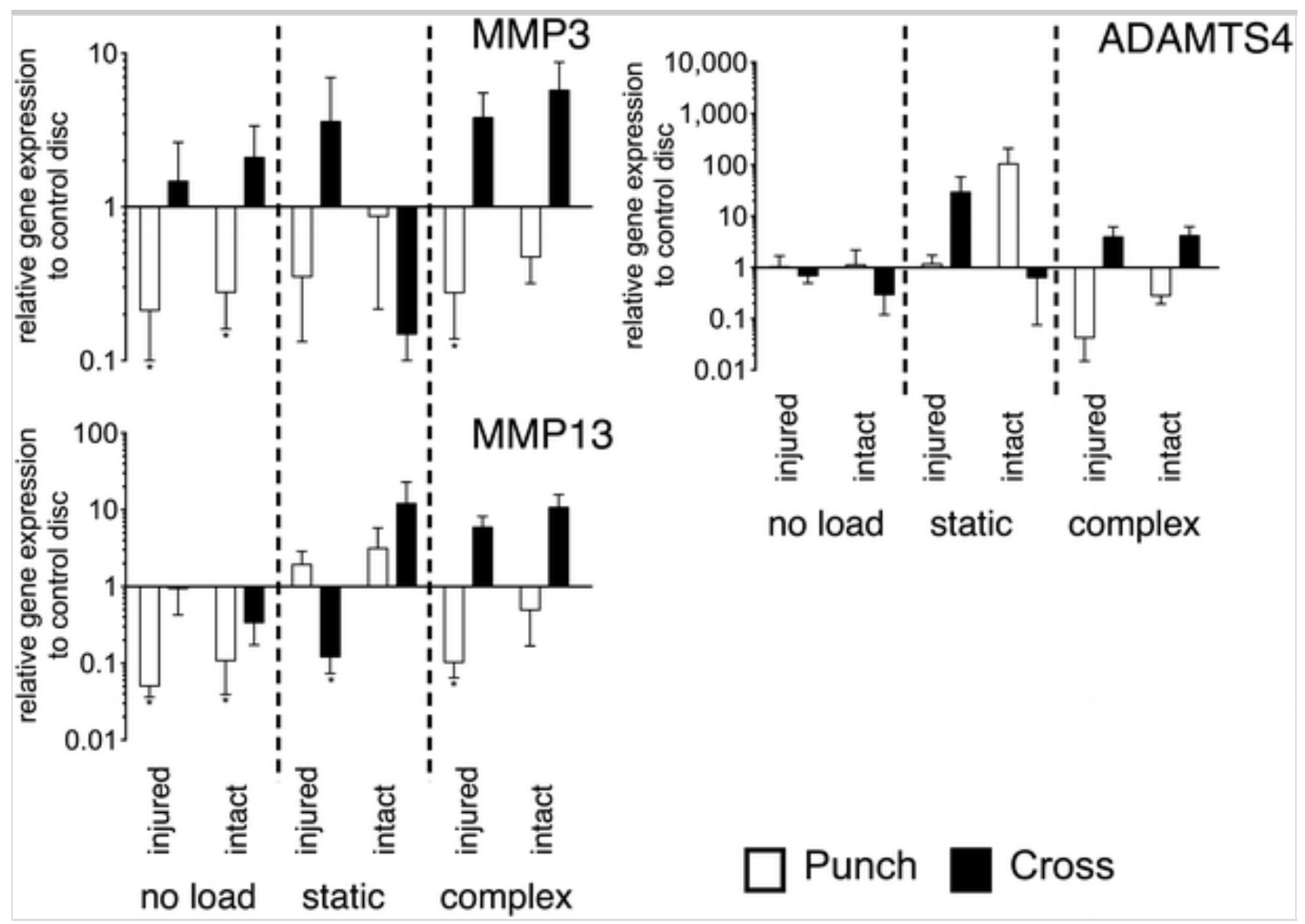

Similarly, in the inflammatory genes, down-regulation was mainly observed for unloaded samples (Fig. 6). In more detail, $I L-1 b$ was down-regulated for the punch in the no-load and injured side group, i.e. 11-fold ( $p$ value $<0.05$ ).

Moreover, cross-incision under no load for the injured side was down-regulated, i.e. sevenfold ( $p$ value $<0.05$ ). For $I L-8$ under no load, all groups were significantly down-regulated $(p$ value $<0.05)$ Furthermore, punch injury caused 
down-regulation under complex load ( $p$ value $<0.05$ ). Comparing effects of the three different loading regimes, we found a significant difference between the two injury models on the injured side under complex load $(\mathrm{K}-\mathrm{W}, p$ value $<0.05$, Fig. 6). For $C C L 2$, punch injury caused significant down-regulation under no load for the injured side $(\sim$ sevenfold $p$ value $<0.05)$ and on the injured under complex load (threefold, $p$ value $<0.05)$. For cross-incision, CCL2 was downregulated for no load on the intact side $(\sim$ threefold $p$ value $<0.05)$. For COX2 gene, we found down-regulation for punch injury for the complex load on the injured side ( $\sim$ twofold, $p$ value $<0.05)$. For $N G F$, both injury models did not cause significant changes from the control.

\section{Fig. 6}

Gene expression of major inflammatory genes. Kruskal-Wallis tests followed by Dunn's multiple pairwise comparison test were performed among experimental groups. Additionally, Wilcoxon signed rank test was calculated to test deviations from the hypothetical value of $1 . P$ values $*<0.05 ; * *<0.01 ; * * *<0.001, N=6$, mean \pm SEM 


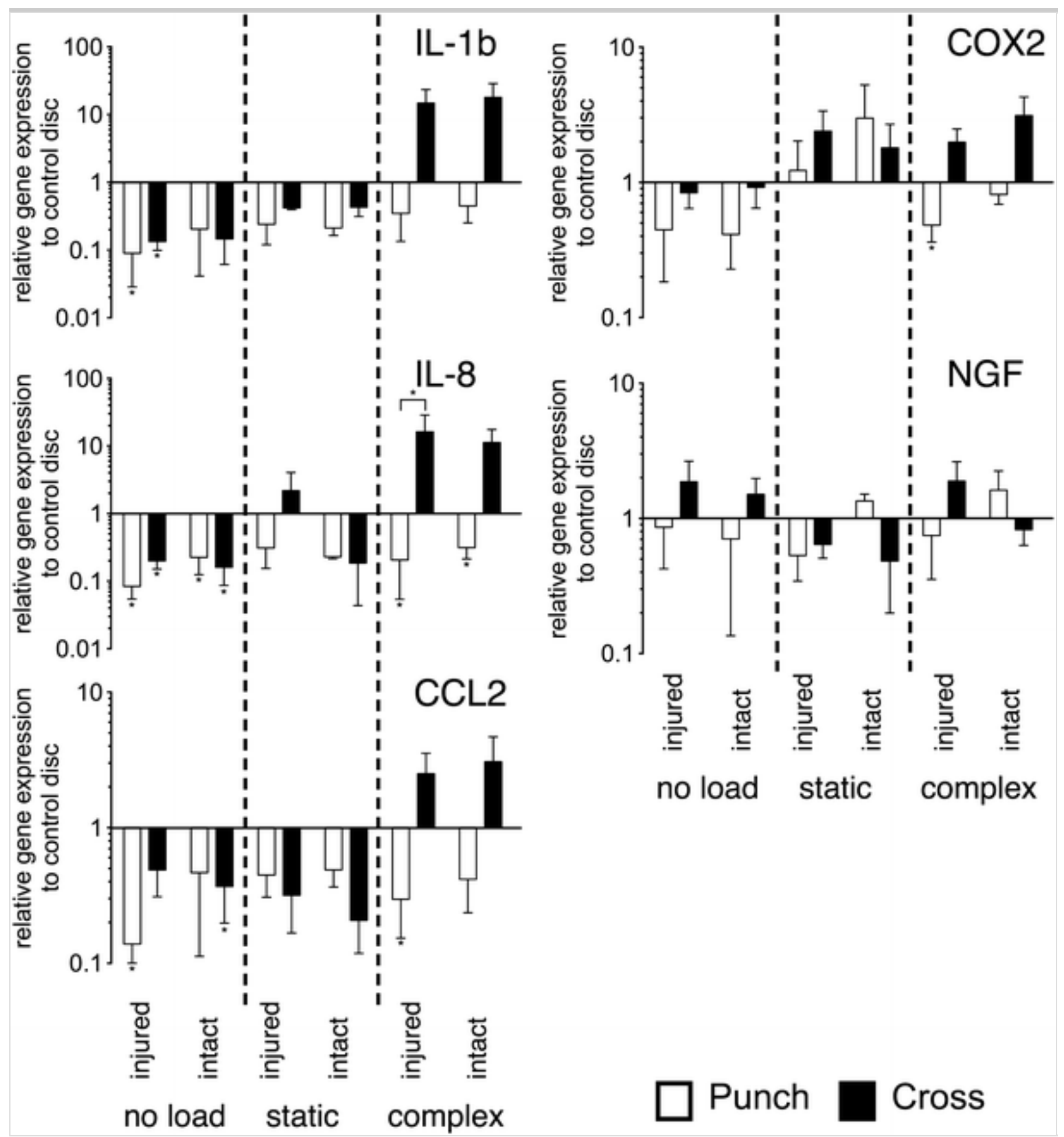

\section{Stiffness}

Compressional stiffness showed a trend towards higher stiffness with culture time for the control (first cycle $95.76 \pm 34.55$ vs. 14 th cycle $295.83 \pm 78.37, p$ value $=0.1$ ) and also an increase in stiffness for the cross-incision (first cycle $83.41 \pm 11.91$ vs. 14 th cycle $382.91 \pm 224.85, p$ value $<0.05)$ but not for punch injury (first cycle $83.14 \pm 55.14$ vs. 14 th cycle $289.79 \pm 91.22, p$ value $<0.2$ ). Among injury models, no significance in compressional stiffness ( $p$ value $>$ 
0.30) was detected, Table 4.

\section{Table 4}

Stiffness $[\mathrm{N} / \mathrm{mm}]($ mean $\pm \mathrm{SEM})$ calculated for first, seventh, and fourteenth complex loading cycle from bioreactor raw data for healthy control disc, 2--mm punch and cross-incision injury

\begin{tabular}{|l|l|l|l|}
\hline Cycle & Control & Punch injury & Cross-incision injury \\
\hline 1 & $95.76 \pm 34.44$ & $83.14 \pm 55.14$ & $83.41 \pm 11.91$ \\
\hline 7 & $164.65 \pm 73.64$ & $238.12 \pm 127.36$ & $238.53 \pm 93.52$ \\
\hline 14 & $295.83 \pm 78.37$ & $289.79 \pm 91.22$ & $382.91 \pm 224.85$ \\
\hline
\end{tabular}

\section{Histology}

In histological sections, punch injury can be seen clearly in transversal sections as they leave a relatively large open space. Cross-incision on the other hand was not possible to observe in neither transversal nor sagittal sections, Fig. 7. Histology of injured discs did not show deviations from the healthy control disc after 14 days of organ culture. Moreover, Safranin-O did not indicate a loss of proteoglycan around the punch injury, and further, H\&E showed only matrix disorganisation at the edge of the injury.

\section{Fig. 7}

Histology of healthy control, punch, and cross-incision injury (top-down) with H\&E, Safranin-O/Fast-Green and Picrosirius Red (left-right). Sagittal cuts are PMMA embedded and transversal cuts are cryosections 


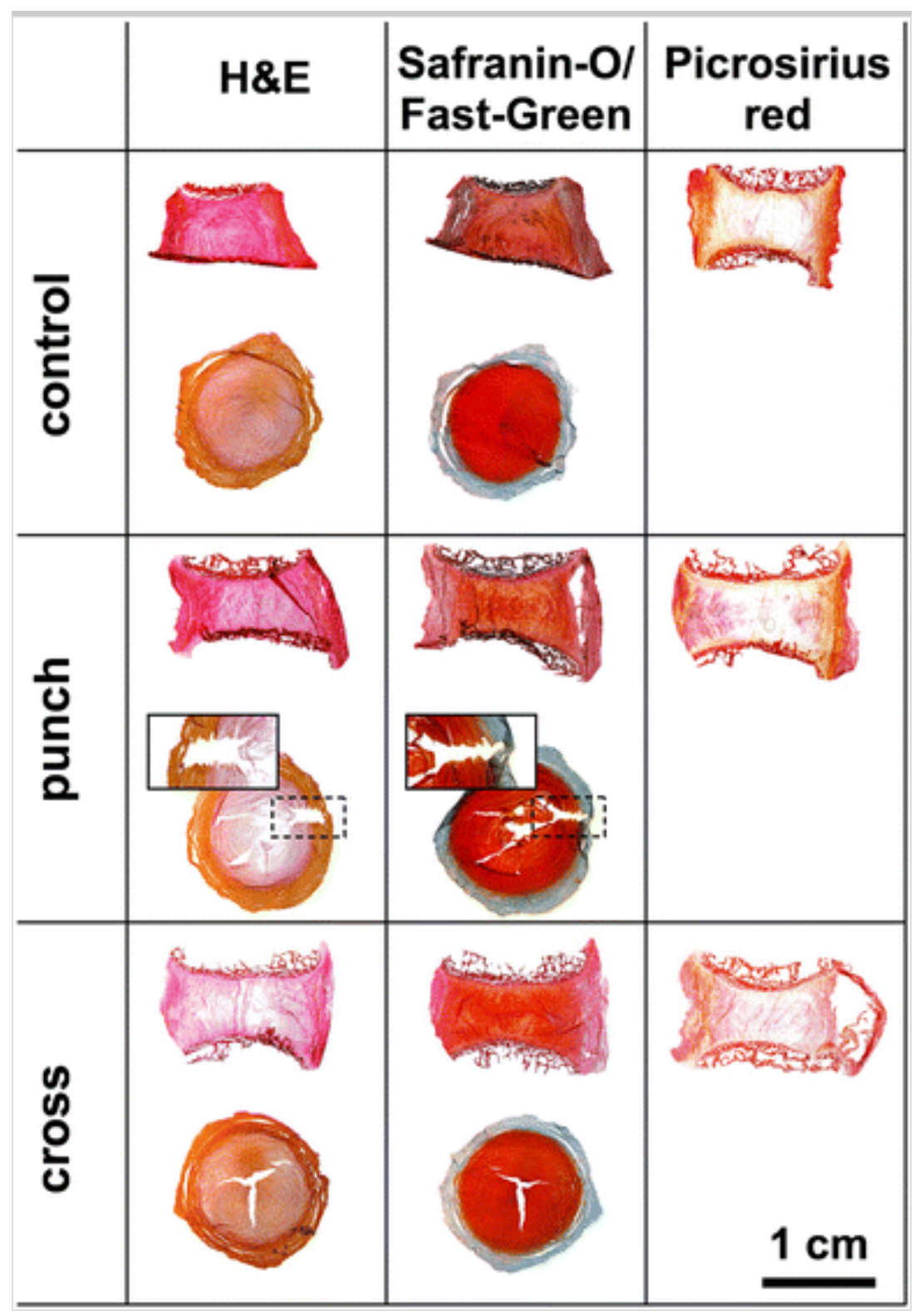

\section{Discussion}

\section{Cross-incision versus punch injury}

Both injury models, 2-mm biopsy punch and 7-mm-depth injury and customdesigned cross-incision tool, were able to create a defined and reproducible injury to bovine IVDs. Despite the big difference in injury appearance, the punch injury is closer to a post-disc herniation surgery situation where extruded NP tissue is removed by disc forceps. The parameters analysed in this study had not been able to show significant differences between injury models; however, bigger sample sizes may be required to state this clearly. More Furthermore ,.., no significant difference between injury models was observed for 
compressional stiffness. The trend to increase stiffness; over culture period, might arise from the culture system used, wherein discs might not fully recover throughout resting phase, hence, possibly leading to a denser and stiffer IVD over culture time.

Our hypothesis that a cross-incision injury would manifest more significant damage, i.e. disc height loss, matrix degradation and decreased cell viability, under complex loading due to the cutting of the AF fibres than under no or static load, was partially confirmed by decreased disc height. Gene expression, however, does not support this, as anabolic genes ( $A C A N, C O L 1, C O L 2$, $C O M P$ ) were mostly in the range of control. However, $B G N$ was up-regulated under complex load for the intact side. Further, it differed significantly from the injured side of the punch-injured IVD (Fig. 4). Additionally, catabolic genes were predominantly not significantly different from the controls. Also, inflammatory genes were mainly down-regulated for no load ( $I L-1 b, I L-8$, CCL2). However, under no load, gene expression was in the range of the control disc and up-regulated catabolic and inflammatory marker genes, see Figs. 3, 5, and 6. As what concerns the DNA content, we found that the mechanical loading profiles were contributing mostly to these effects. In the case of GAG content, an improvement from static to complex loaded samples could be observed. This recovery under load was previously observed by Rosenzweig et al. [15] and Gawri et al. [16].

When comparing this to the punch injury, it can be observed that reduction in mitochondrial activity, GAG, and DNA contents is mainly present in the noload or static load cultures. As for the cross-incision, an improvement in DNA content was observed for complex loading, confirming recent findings that some kind of mechanical loading seems beneficial for joint explant cultures [1, 17]. However, when comparing gene expression, anabolic genes (COL1, BGN, $C O M P$ ) do show down-regulation, whereas cross-incision did up-regulate $B G N$ but did not induce significant changes in the other genes tested. Further, $M M P 3$, $M M P 13$, and ADAMTS4 were all down-regulated, while cross-incision did not differ significantly from the control. This pattern was repeated by the inflammatory genes ( $I L-1 b, I L-8, C C L 2$, and COX2), which were downregulated for punch injury, while cross-incision did not cause significant changes. This might indicate that the punch injury under complex load is not capable of evoking inflammatory or regenerative reactions. Cross-incision did 
not suppress these completely and might be able to induce regeneration with longer culture time.

Both injury models do show different behaviours in dependence on the loading regime applied, mainly for complex load where torsion was applied. Under complex loading, which corresponds in our experimental design to the most physiological model, punch and incision model showed mainly opposite effects on pro-inflammatory and catabolic gene expression, whereas with punch caused down-regulation and cross-incision causing up-regulation. It would be interesting to see the responses of a combined damage model using first AF incision injury followed by a time-delayed discectomy. Such injuries could even mimic more complex and more realistic clinical situations of trauma. This is of importance for future investigation for testing novel biomaterials for repair of disc herniation or after disc herniation surgery to close the AF to prevent reherniation of the disc [18]. To do so, the applied loading regimes are of importance as the goal is to restore the patients' normal biomechanics. The cross-incision injury, on the other hand, mimics a pre-herniation state, where the AF has fissures that upon prolonged or overloading might result in disc herniation. Here, new techniques and materials could be evaluated for their feasibility to maintain disc health and assess how these perform under different loading regimes.

Interestingly, it was observed for both injury models that the changes in gene expression and biochemical assays often affected both tissue samples, either taken from the injury side or the contralateral side. Hence, we conclude that both injuries did not only affect the IVD locally but, indeed, affected the whole disc. At first sight, this finding seems to contradict the data by Walter et al. [19] where asymmetric compression caused significant differences between the concave and convex sides of the same disc in catabolic gene expression, i.e. $M M P 1, A D A M T S 4, I L-1 b$, and $I L-6$. However, in this study, a completely asymmetrical loading was applied. Our finding of whole disc engagement, however, is in agreement with by a previous study by Iatridis et al. (2009) [3], who found organ-level effects of induced injuries into the whole motion segment in reduced cellularity and biomechanics-of biomechanies. Further, Melrose et al. [20] also observed an interference of the contralateral side after induction of a 4-mm-deep and 10-mm-wide scalpel incision in an in vivo ovine animal model. Our study does not provide the proct reasons for that 
effect., However, but we speculate that due to the changed biomechanics, the contralateral side was is also affected. More, pro-inflammatory cytokines released due to the injury may then affect the whole disc negatively in the gene expression and biochemical assays tested. The second scenario might be further enabled by our organ culture setup where the whole discs are immersed in approximately $35-40 \mathrm{~mL}$ of medium that is exchanged every two to three days. However, the media was not investigated for such cytokines neither in this study nor by other similar experimental setups $[2,7,19]$.

\section{Conclusion}

- Cross-injury model led to a significant height decrease under complex loading.

- Furthermore, under complex loading, punch injury caused general downregulation of anabolic, catabolic, and inflammatory genes, whereas the cross-injury resulted in non-significant changes for catabolic and inflammatory genes and up-regulation of $B G N$.

- Punch injury possibly is a very severe injury causing general downregulation of inflammatory cytokines in organ culture.

- Cross-incision damage resulted in a trend to up-regulate inflammation genes, such as $I L-1 \beta, I L-8$, and $C C L 2$ and $C O X 2$ under complex loading.

- In our organ culture setup, the whole disc organ was affected by both types of injuries regarding mitochondrial activity, GAG, and DNA contents, and gene expression of major catabolic, anabolic, and inflammatory genes.

\section{Acknowledgements}

We thank Eva Roth for her valuable assistance in IVD isolation and biochemical assays. Further, we thank Dimitrios Damopoulos for his assistance with the bioreactor data analysis. This project is supported by athe Swiss National Science Project \#310030_153411 and by the Gebert Rüf Foundation \#GRS$028 / 13$.

Compliance With ethical standards 
Conflict of interest All authors declare that they have no conflict of interest.

\section{Electronic supplementary material}

Below is the link to the electronic supplementary material.

Supplementary material 1 (PPTX $464 \mathrm{~kb})$

\section{References}

1. Gantenbein B, Illien-Jünger S, Chan SC, Walser J, Haglund L, Ferguson SJ, Iatridis JC, Grad S (2015) Organ culture bioreactors-platforms to study human intervertebral disc degeneration and regenerative therapy. Curr Stem Cell Res Ther 10(4):339-352. https://doi.org/10.2174/1574888X10666150312102948

2. Korecki CL, Costi JJ, Iatridis JC (2008) Needle puncture injury affects intervertebral disc mechanics and biology in an organ culture model. Spine 33(3):235-241. https://doi.org/10.1097/BRS.0b013e3181624504

3. Iatridis JC, Michalek AJ, Purmessur D, Korecki CL (2009) Localized intervertebral disc injury leads to organ level changes in structure, cellularity, and biosynthesis. Cell Mol Bioeng 2(3):437-447. https://doi.org/10.1007/s12195-009-0072-8

4. Michalek AJ, Buckley MR, Bonassar LJ, Cohen I, Iatridis JC (2010) The effects of needle puncture injury on microscale shear strain in the intervertebral disc annulus fibrosus. Spine J 10(12):1098-1105. https://doi.org/10.1016/j.spinee.2010.09.015

5. Michalek AJ, Iatridis JC (2012) Height and torsional stiffness are most sensitive to annular injury in large animal intervertebral discs. Spine J 12(5):425-432. https://doi.org/10.1016/j.spinee.2012.04.001

6. Mariconda M, Galasso O, Attingenti P, Federico G, Milano C (2010) 
Frequency and clinical meaning of long-term degenerative changes after lumbar discectomy visualized on imaging tests. Eur Spine J 19(1):136-143. https://doi.org/10.1007/s00586-009-1201-8

7. Li Z, Lezuo P, Pattappa G, Collin E, Alini M, Grad S, Peroglio M (2016) Development of an ex vivo cavity model to study repair strategies in loaded intervertebral discs. Eur Spine J 25(9):2898-2908.

https://doi.org/10.1007/s00586-016-4542-0

8. Adams MA, Green TP (1993) Tensile properties of the annulus fibrosus.

I. The contribution of fibre-matrix interactions to tensile stiffness and strength. Eur Spine J 2(4):203-208

9. XXX

10. XXX

11. Adams MA, Roughley PJ (2006) What is intervertebral disc degeneration, and what causes it? Spine 31(18):2151-2161. https://doi.org/10.1097/01.brs.0000231761.73859.2c

\section{2. $\mathrm{XXX}$}

13. Farndale RW, Buttle DJ, Barrett AJ (1986) Improved quantitation and discrimination of sulphated glycosaminoglycans by use of dimethylmethylene blue. Biochim Biophys Acta BBA Gen Subj 883(2):173177. https://doi.org/10.1016/0304-4165(86)90306-5

14. Livak KJ, Schmittgen TD (2001) Analysis of relative gene expression data using real-time quantitative PCR and the 2(-Delta Delta C(T)) method. Methods 25(4):402-408. https://doi.org/10.1006/meth.2001.1262

15. Rosenzweig DH, Gawri R, Moir J, Beckman L, Eglin D, Steffen T, Roughley PJ, Ouellet JA, Haglund L (2016) Dynamic loading, matrix maintenance and cell injection therapy of human intervertebral discs cultured in a bioreactor. Eur Cell Mater 30:26-39.

https://doi.org/10.22203/eCM.v031a03 
16. Gawri R, Moir J, Ouellet J, Beckman L, Steffen T, Roughley P, Haglund L (2014) Physiological loading can restore the proteoglycan content in a model of early IVD degeneration. PLoS ONE 9(7):e101233.

https://doi.org/10.1371/journal.pone.0101233

17. Paul CP, Schoorl T, Zuiderbaan HA, Zandieh Doulabi B, van der Veen AJ, van de Ven PM, Smit TH, van Royen BJ, Helder MN, Mullender MG (2013) Dynamic and static overloading induce early degenerative processes in caprine lumbar intervertebral discs. PLoS ONE 8(4):e62411. https://doi.org/10.1371/journal.pone.0062411

18. Parker SL, Mendenhall SK, Godil SS, Sivasubramanian P, Cahill K, Ziewacz J, McGirt MJ (2015) Incidence of low back pain after lumbar discectomy for herniated disc and its effect on patient-reported outcomes. Clin Orthop Relat Res 473(6):1988-1999. https://doi.org/10.1007/s11999015-4193-1

19. Walter BA, Korecki CL, Purmessur D, Roughley PJ, Michalek AJ, Iatridis JC (2011) Complex loading affects intervertebral disc mechanics and biology. Osteoarthr Cartil 19(8):1011-1018.

https://doi.org/10.1016/j.joca.2011.04.005

20. Melrose J, Smith SM, Fuller ES, Young AA, Roughley PJ, Dart A, Little CB (2007) Biglycan and fibromodulin fragmentation correlates with temporal and spatial annular remodelling in experimentally injured ovine intervertebral discs. Eur Spine J 16(12):2193-2205. https://doi.org/10.1007/s00586-007-0497-5

21. Hsieh AH, Hwang D, Ryan DA, Freeman AK, Kim H (2009) Degenerative anular changes induced by puncture are associated with insufficiency of disc biomechanical function. Spine 34(10):998-1005. https://doi.org/10.1097/BRS.0b013e31819c09c4

22. Hu MH, Yang KC, Chen YJ, Sun YH, Lin FH, Yang SH (2017) Optimization of puncture injury to rat caudal disc for mimicking early degeneration of intervertebral disc. J Orthop Res 36(1):202-211. 
https://doi.org/10.1002/jor.23628

23. Martin JT, Gorth DJ, Beattie EE, Harfe BD, Smith LJ, Elliott DM (2013) Needle puncture injury causes acute and long-term mechanical deficiency in a mouse model of intervertebral disc degeneration. J Orthop Res 31(8):1276-1282. https://doi.org/10.1002/jor.22355

24. Michalek AJ, Funabashi KL, Iatridis JC (2010) Needle puncture injury of the rat intervertebral disc affects torsional and compressive biomechanics differently. Eur Spine J 19(12):2110-2116. https://doi.org/10.1007/s00586010-1473-z

25. Przybyla A, Pollintine P, Bedzinski R, Adams MA (2006) Outer annulus tears have less effect than endplate fracture on stress distributions inside intervertebral discs: relevance to disc degeneration. Clin Biomech Bristol Avon 21(10):1013-1019. https://doi.org/10.1016/j.clinbiomech.2006.07.003

26. Kääpä E, Han X, Holm S, Peltonen J, Takala T, Vanharanta H (1995) Collagen synthesis and types I, III, IV, and VI collagens in an animal model of disc degeneration. Spine 20(1):59-66 discussion 66-7

27. Rousseau MA, Ulrich JA, Bass EC, Rodriguez AG, Liu JJ, Lotz JC (2007) Stab incision for inducing intervertebral disc degeneration in the rat. Spine 32(1):17-24. https://doi.org/10.1097/01.brs.0000251013.07656.45

28. Illien-Jünger S, Lu Y, Purmessur D, Mayer JE, Walter BA, Roughley PJ, Qureshi SA, Hecht AC, Iatridis JC (2014) Detrimental effects of discectomy on intervertebral disc biology can be decelerated by growth factor treatment during surgery: a large animal organ culture model. Spine J 14(11):27242732. https://doi.org/10.1016/j.spinee.2014.04.017

29. Sobajima S, Kompel JF, Kim JS, Wallach CJ, Robertson DD, Vogt MT, Kang JD, Gilbertson LG (2005) A slowly progressive and reproducible animal model of intervertebral disc degeneration characterized by MRI, Xray, and histology. Spine 30(1):15-24.

https://doi.org/10.1097/01.brs.0000148048.15348.9b 
30. Xin L, Xu W, Yu L, Fan S, Wang W, Yu F, Wang Z (2017) Effects of annulus defects and implantation of poly(lactic-co-glycolic acid)

(PLGA)/fibrin gel scaffolds on nerves ingrowth in a rabbit model of annular injury disc degeneration. J Orthop Surg Res 12(1):73.

https://doi.org/10.1186/s13018-017-0572-5

31. Likhitpanichkul M, Dreischarf M, Illien-Junger S, Walter BA, Nukaga T, Long RG, Sakai D, Hecht AC, Iatridis JC (2014) Fibrin-genipin adhesive hydrogel for annulus fibrosus repair: performance evaluation with large animal organ culture, in situ biomechanics, and in vivo degradation tests. Eur Cell Mater 28:25-38. https://doi.org/10.22203/eCM.v028a03

32. Dudli S, Haschtmann D, Ferguson SJ (2014) Persistent degenerative changes in the intervertebral disc after burst fracture in an in vitro model mimicking physiological post-traumatic conditions. Eur Spine J 24(9):19011908. https://doi.org/10.1007/s00586-014-3301-3

33. Dudli S, John Ferguson S, Haschtmann D (2014) Severity and pattern of posttraumatic intervertebral disc degeneration depends on the type of injury. Spine J 14(7):1256-1264. https://doi.org/10.1016/j.spinee.2013.07.488

34. Dudli S, Boffa DB, Ferguson SJ, Haschtmann D (2015) Leukocytes enhance inflammatory and catabolic degenerative changes in the intervertebral disc after endplate fracture In Vitro without infiltrating the disc. Spine 40(23):1799-1806. https://doi.org/10.1097/BRS.0000000000001186 